\title{
SEMIOTIC ANALYSIS IN WILLIAM BLAKE POEMS
}

\author{
Husnul Hatima Adudu, Dahlia Husain \\ English Literature Department, Cultural Sciences Faculty, \\ Muhammadiyah University of Gorontalo
}

\begin{abstract}
Semiotic Analysis in William Blake Poems. The problem in this research is how to apply Riffaterre's theory. This research focused on semiotic of Riffaterre's theory in William Blake poems, titled The Sick Rose, My Pretty Rose Tree, and The Garden of Love. The method that used in this research was descriptive qualitative method. The data that used in this research was a written record in the form of three poems by William Blake. Three poems in question were The Sick Rose, My Pretty Rose Tree, and The Garden of Love. The technique used to collect data in this research was the technique of reading log. The researcher used the Riffaterre's theory to analysis the poems. Based on the analysis, it can be concluded that poem The Sick Rose and The Garden of love depict of live before France Revolution occurred, and poem My Pretty Rose Tree describe about the author's feeling to his wife.
\end{abstract}

Keywords: Poetry, Semiotic, Riffaterre's Theory.

\section{INTRODUCTION}

Literature is the work of imaginative writers. Authors write down their ideas, life experiences, view of life, which they gain surroundings communities where they live. The literature emerged from innate love of storytelling, arrangement of words in pleasing patterns, revealed in the words of some specific aspects of human experience. This is usually specified in a character that was created to make it more easily to be understood though largely done on particular social events (Moody, 1984:2). From these statements, it is clear that literature discusses about the human experience. This is an expression of life in the words of truth and beauty. It is also a written record that is the aspirations, thoughts, and emotions as well. Many people do not realize that everything in the literature 
contains an awful lot of value that can be applied in life, for that is why literature is very important. Truth literature can also provide the truth and satisfaction.

There are several branches in literature include drama, poetry, and prose. In this case it is poetry. Poetry as a literary work of art is aesthetic and meaningful work that has meaning, symbol, intent, and not just something empty without meaning. Poetry is the expression of the thought which have the imagination, stimulate the five senses in a rhythmic arrangement. All of that is important, which is recorded and is expressed and manifested with interesting and gives the impression. In other words, poetry is the recording and interpretation of the human experience, and modified in a most memorable.

A poem is composed by a beautiful language and structured, which can lead us to a feeling and intent of a poem itself. Most of the readers of poem are those who indeed basically liked the poems, the beauty of its language, or moderate of poem describe moods at the time. However, in understanding poem the reader must be able to capture the intent and purpose of the meaning between the lines in a poem which should be studied more in depth. In order to understand poetry in depth, we must know how to use style of the language and understand the whole poetry by way of analyzing the existing structure. To analyze the structure, a poem can be analyzed by using the approach of structuralism. In literary theory, structuralism is an approach to analyze the narrative material by examining the underlined invariant structure, which is based on the linguistic sign system of Riffatere. The elements do not have meaning by itself so poetry represent the sign structure which have a meaning and have a system, an analysis also linked up with semiotic analysis.

In semiotic analysis, poetry is usually supported by certain element to enrich the meaning and bring the writer's mind to the reader's imagination. The elements in a poem called intrinsic elements such as figure of speech, rhyme, rhythm; 
imagery and tone enrich the meaning and make the reader's easily understand the meaning of the poem.

Semiotic discusses about signs or symbols. In this case the researchers analysis the signs or symbols in three poems of William Blake namely, The Sick Rose, My Pretty Rose Tree, and The Garden of Love. William Blake is one of the many poets use symbols in his poetry. As in the poem of Blake's, there is several symbols in his poems such as Rose, Flower, and Love. The researcher is interested in study symbolism in the poems by William Blake, using semiotic of Riffaterre. According to Ratna (2016:7), Riffatere theory is chosen because the language in poetry is dense and uses diction that is unusual compared to other semiotic approach, because the steps in the process its analysis includes the reading of the heuristic, indirect expression that includes the displacing of meaning, distorting of meaning, and creation of meaning, as well as the reading of the hermeneutic that is done in order to obtain the meaning of the poem as a whole so that it can be found desired meanings conceived by the researcher and the reader. Therefore, the title of this research as "Semiotic Analysis in William Blake's Poems". This poem is choosen because Blake's uses many symbols to his poems. This research is to understand the use of semiotic by Riffaterre in Blake's poem.

\section{Research Method}

This study used qualitative methods. Qualitative method is to describe a situation without formal testing or hypothesis, and it makes little or no use of numbers but rather focuses on "thick description". Kane in Kaelan (2009:15) explains that descriptive is about sensory experience how something looks, sounds, tastes. Mostly it is about visual experience, but description also deals with other kinds of perception.

In this research the researcher also applied semiotic of Riffatere. According to Ratna, (2004:49) semiotic of Riffatere is the theory that defends that dotted the 
language in poetry is a sign system that contains the indirect expression. Readers give the meaning of signs on literary work, so that the whole meaning of unity obtained.

The researcher applied Riffattere's theory in analyzing symbol by describing the heuristic and hermeneutic, describe the matrix, model, variant, and the hypogram in Blake's poem.

Technique of Collecting The Data

This research use documentation as the technique of collecting the data. According to Bogdan in Sugiyono (2013:82), in most tradition of qualitative researh, the phrase personal document is used broadly to refer to any first person narrative produced by an individual which describes hir or her own actions, experience and belief.

In this research, all of the required data is collected to do more research. The first step is the researchers chose three poems of Blake. The second step, researchers classify the poetry of Blake uses Riffaterre theories.

Technique of Analyzing Data

There are some techniques of analyzing the data according Miles and Huberman in Sugiyono (2013:95) as follow :

1) Data Reduction.

It is the process of sorting, focusing, simplifying, abstracting, and transforming of the raw data. Data reduction occurs continously during the process of conducting qualitative research. The researcher have been reduce the data before, during, and after collecting the data as well as analyzing the data. In this step, researcher use data reduction in Blake's poems to analyze the data.

2) Data Display.

Looking at displays help the researcher to understand what is happening and to do some thing-further analysis or caution on that understanding. Data display done in the form of brief description, chart, relations between categories, and flowchart. 
By data display, the researcher is easy to understand in analyze three poems of Blake's.

3) Conclusion/Verification.

The last step of analyzing the data is conclusion/verification.The researcher get the conclusion of the result. Then, the results of analysis is test for reliability and validity through triangulation. It is an attempt to check the truth of the data or information obtained by researcher from different perspectives as much as possible by reducing the bias that occurs during data collection and analysis. It is aimed to get trustworthiness, validity, and reliability of the data and also make final conclusion of the data that analyze, interpreted, and identified in the preceding process.

The researcher find the conclusion/verification of analysis Blake's poems after find out the data reduction and data display.

\section{RESEARCH FINDING AND DISCUSSIONS}

In this discussion, the researcher discuss about the symbols by using Riffaterre's theory that described in research findings. Riffaterre's theory is a theory that is used to analyze the poem in order to get the meaning of the whole poem. This is similar to Ratih (2016: 5), that said Riffaterre's using a special meaning, it is to giving the meaning of literature as a system of signs. Riffaterre's theory is used to poem analysis and leads to the meaning of literary works. The discussion are follow:

\section{Heuristic and Hermeneutic Reading}

Poetry expresses something indirectly. So, in the heuristic reading of poem, logic of language that is un usual developed in the logic of ordinary language that easily understood. Culler in Pradopo (2010: 296) state, that all un usual made outstanding or to be naturalized accordance the system of normative language. When necessary, the words given the prefix or suffix, and inserted the relations of words that can make poem became clear. 
The reading of the second stage is hermeneutic. Heuristic reading is a form of interpretation of poem from beginning to the end. So its discovered the true meaning to be conveyed by the author of poem. The researcher Analyzed it based on Pradopo's (2010: 297), that the hermeneutic reading or retroactive is re-reading from beginning to end with the interpretation. This reading is based on the literary convention of giving meaning. Poetry expresses the idea indirectly, with the figure (metaphor), ambiguity, contradiction, and organizing space of the text (visual signs).

\section{Poem : The Sick Rose}

In the data findings 1 in heuristic reading, researchers describe the heuristic reading in this poem. In stanza 1 line 1 depicts a rose that can be interpreted sick or wilted. In the data findings 2 , line 2 is a worm invisible. Line 2 is the result of a line 1 . Where roses pain caused by a worm. In data findings 3 , line 3 , has the meaning which fly at night. Something flew indicates a worm. Data finding 4, in line 4, means the big storm hit. The word 'howling' in the real sense was a hoot. But researchers concluded the intent of the word is a metaphor of a masher.

In the data finding 5 of this poem, in stanza 2 line 1 is a rose and worm found out the bed. In data finding 6, line 2, have meanings have found beds excitement of a dark red. In the data finding 7, line 3 is indicates the dark secret love (of the worm and rose).in the data finding 8 , line 4 , does the life of rose will destroy". This line seemed into question the love story of the worm and rose, whether the future will destroy them.

The over all of heuristic reading in this poem tells about a rose and a worm that causes pain of rose, because basically the nature of the worm is a destroyer. At the time of night where there is a storm, this worm fly and carried by the storm and in to the soil and take the soil essence where the roses plant. Worms seemed to find a place that makes him happy. But actually the rose is harmful. But roses 
still enjoy, and do not think about what would happen to her later, if the worms remain in the soil where the roses grow.

The hermeneutic reading in this poem is;

In the data finding 9, stanza 1 line 1 , there is an ambiguous word in this poem is the word 'rose'. These words mark a woman who is being sad. As stated by Badrun (1989: 54), that ambiguity is usually called a double meaning. Each person can interpret words or events with a variety of different ways. Giving meaning to the ambiguous is up to the reader and the interpretation should start from the context of the overall text. Right or not the meaning, depends on the reason. Therefore, the reader is free to interpret, because the words have variety of meanings. Such as in data finding 10, line 2, which depicts a worm that marks a man or a masher man who has stolen something value that is owned by the woman. In the data finding 11 , line 3 , a worm is always flies in the night, in the data finding 12, tells about a man that shattered a woman's life.

In the data finding 13, stanza 2 line 1 a man invite the woman to sleep together, and in data finding 14 line 2, the speaker's said that the man and a woman is enjoy their relationship even that is not good for both of them. In data finding 15, line 3, the speaker's explains that the man and woman hiding their relationship or in the other words being secretive of relationship, with the other reason, maybe this man had a wife. In data finding 16, line 4 doe life of the woman destroy because of a man.

This poem is about a woman who are sick because of something valuable from her has been lost because of lust and love with a man. She was experiencing pain as a result of her actios. And a man is the cause of all Suffering and sorrow in the woman's life. She is only enjoying the night life without thinking aboout the consequences. And it is shown in the last line "and his dark secret love does thy life destroy." 


\section{Poem : My Pretty Rose Tree}

In the data finding 17line 1, the speaker's say, there is a beautiful rose that offered to him, in the data finding18 line 2, the speaker's depict thatthe rose is never bore to see, even that rose looks very charming. In data finding 19 in line 3, the speaker's says that he was not interested because he already has a rose no less admirable. In data finding 20line 4, the speaker's pass the flower who offered her love. In data finding 21 line 5, the speaker's went to see her roses. In data finding 22 line 6,the speaker's caring for the rose every day. In data finding 23 line 7 , the roses go with jealousy and in data finding 24 , the only thing that the roses left is just a thorn, at least able to make the speaker's happy.

In hermeneutic reading, data finding 25 , line 1 , a flower symbolizes a woman who tried to persuade the speaker's to replace that speaker's wife at home. In the data finding 26 , line 2 , the beautiful woman said that the man will not feel bored with her. It indicate from line 3 of the poem, in the data finding 27, And rose in this poetry is symbolize a woman (the speaker's wife) who always accompany her husband at home. In the data finding 28 , line 4 , is illustration that the speaker's who ignore the temptation of a woman who declares her love. In the data 29 , line 5 is explain about the speaker's who is always faithful to his wife and in the data 30 line 6, the speaker's always keep his wife everyday. In the data finding 31 line 7, the wife's of the speaker's get jealousy to the woman that offer her love to her husband. In the data finding 32 , line 8 , explain about the speaker's always be honest with his wife, including when there is another woman who seduce him. She is the special one in her husband's life.

\section{Poem : The Garden of Love}

In the data finding 33, stanza 1 line 1, the speaker's go to a garden with filled of love, in the data 34, the speaker's only found something that he never seen before. In the data 35, that is a church located in the midst of the garden, and in data 36 , where the speaker's use it to play. 
In the data finding 37, stanza 2 line 1 describes the gates of the church were closed and in the data finding 38 line 2 , the front door is clearly written that the church is banned. This means that not just anyone is allowed to enter the church. In data finding 39 line 3, the speaker's look around the garden, in the data finding 40 line 4 , but the flowers are not as much as before and now seemingly very boring to look at.

In the data finding 41, line 1, the speaker's saw in the garden there is graves. But in the data finding 42, The speaker's thinks that the grave should not be there, where beautiful flowers grow. In data finding 43, line 3, the pastors walking and may surround the graves by wearing black clothes. In data finding 44line 4, pastors is barricate the happiness and desire.

The hermeneutic reading in poem My Pretty Rose Tree is:

In data finding 45, stanza 1 line 1 , as the researcher stated that 'garden of love' is not a place that full of flower, but it is describe the condition of society has changed a lot. And in the data finding 46, line 2, the speaker's see something strange that he never see before. In the data finding 47 , line 3 , is about there is a church was built and make significant changes. In the data finding 48 , line 4 , the condition of society where the speaker's live is change.

In data finding 49, stanza 2 , line 1 describes a church that was closed to the public because only certain people can get into the church. Data finding 50line 2, at the time the church was built, the situation has changed because of the church's teachings deviate. In the data finding 51, line 3 , the speaker's observe the condition of society and in the data finding 52 line 4 , stated that where there is a lot of significant changes.

In data finding 53, stanza 3, line 1, the speaker's see that the garden is full of graves, in the data finding 54line 2, where the flowers should be plant in there. In data finding 55 , line 3 , tells the priests who run the deviant teachings, the data finding 56line 4, and people seemed to be forced to follow. 
This poem describes the society that change a lot of time. There are so many deviations of religion is considered as a room that can not be touched by the ordinary. The minister made the place a holy place, but in fact, it is just a form of reviews their authority. It is described in the first line of the second stanza.

Matrix, Model, and Varian

To "unlock" the rhyme so that it can be easy to grasp, in the concrete poetry, must be searched for matrix or words (keywords).

Keywords are the words that became the key to the interpretation of the verse that concrete and matrix became the source of the entire existing meaning in each word or sentence that is present in literary works (poetry). The matrix can be words, phrases, clauses or simple sentences. The first actualization of the matrix is a model that can be either a specific word or phrase. This model was later expanded to variants thus lowering the overall text (Ratih, 2016: 7).

\section{Poem : The Sick Rose}

In data finding 57 , the poem is about image of a woman whose life is suffering. Models in the poem "The Sick Rose" is "and his dark secret love". Line of poetry is poetic. This is similar to Ratih (2016:41) that said, model is opportunity of the poem, characteristic of model is poetic. So, based on Ratih, the researcher found model. Model 'secret love' is associated with the following line of poetry below.

The invisible worm (line 2)

That flies in the night (line 3)

In the howling storm (line 4)

Has found out thy bed (Stanza 2, line 1)

Of crimson joy (Stanza 2, line 2)

Stanza 2, line 5 and 6 of poetry above describes the events that led to the man affair. To cause the woman to feel the pain. Model 'and his dark secrret love' 
is expansion into variants spread throughout the poem (Ratih, 2016:7). There is (1) O Rose, thou art sick, (2) the invisible worm.

The first variant, 'O Rose, thou art sick', confirms that a woman was ill. Pain experienced by women is very easy to suffer. Researchers visualize this variant in a row:

The invisible worm (Stanza 1, line 1)

That flies in the night (line 3)

In the howling storm (line 4)

The first variant is the cause why she felt hurt and why did the man chose to go and in the end chose another woman and had an affair. In addition, in the second variant, 'and his dark secret love', emphasizing words that describe that true, the man underwent a relationship with another woman or an affair. This variant is visualized in a row:

Has found out thy bed (Stanza 2, line 1)

Of crimson joy (line 2)

And his dark secret love (line 3)

Does thy life destroy (line 4)

The second variant is a description of the act of the man. As a result of these actions, that woman is miserable, and felt crushed.

After the researchers determined the variants, it is also well-known matrix. Because of matrix is a keywords of poem, the researcher found matrix in this poem is 'The Sick Rose'. Because it isexplain a person's that suffering due to love. Indeed, the suffering will be pain caused by love will greatly affect the life.

\section{Poem : My Pretty Rose Tree}

In the data finding 58, Models in this poem is "and her thorns were my only delight". Besides the poetic, the author depicts the feelings of his wife. Memories are the only thing that is left by his wife. As the models, variants and matrix lines of this poem. 
Line poetry above, explain loyalty by the speaker's to his wife. But his wife is jealous and thought her husband is cheating on him. So she left him. And the only thing the wife left to the speaker's life is memories that they ever pass.

Model "and her thorns my only delight" is developed through variants that spread throughout the poem. The first variant "a flower was offered to me" signifies a woman who expresses her feelings to the speaker's. The woman is very charming woman, and likened to a flower that will never get bored if they are viewed. This is equivalent to lines of poetry below.

A flower was offered to me (line 1)

Such a flower as may never bore (line 2)

But I said I've a pretty rose tree (line 3)

And I passed the sweet flower o'er. (line 4)

In the second variant, "but my rose turned away wit Jealousy" indicate of jealousy by the speaker's wife. Because the speaker's wife thought her husband is cheating. This second variant, is faithfulness of speaker's to his wife. But his wife is jealous and thought her husband is cheating on him. So she left him.

The matrix in this poem is the wife of the speaker's jealous and feeling betrayed. These poems is a misunderstanding betweenthe speaker's and his wife, and his wife feel jealous.

\section{Poem : The Garden of Love}

In data finding 59, Model in this poem is "that so many sweet flowers bore". Besides poetic, this word became a model because it is a picture of the circumstances that look boring, there are significant changes in the environment of the community.

The first variant "a chapel was built in the Midst" is the description that the speaker's has built a church in the middle of an environment in which people at that time still not willing with the construction of the church. This relates to the content of the poem in the first stanza. 
I went to the garden of love

And saw what I never had seen

A chapel was built in the midst (stanza 1, line 1)

(line 2)

(line 3)

In the second variant, "and the gates of this chapel were shut". This variant describes the church which is not open to the public. And the church has changed functions where people come to worship the god, but the pastors at the church might teach something different from the teachings embraced by the community. In the third variant, "and I saw it was filled with graves" is a poem that explains that the speaker's saw something different. It is graves were located near the church.The matrix in this poem is the source of all meaning in every word or phrase in the poem, which is the condition of society at that time a lot of changes. And there are so many deviations of religion is considered as a room that can not be touched by the ordinary. The minister made the place a holy place, but in fact, it is just a form of their authority.

Hypogram

Study hypogram intended as a study of literary texts, which is alleged to have forms of certain relationships, for example, to find their relationships intrinsic elements such as ideas, events, plot, characterization, style, and others, within the text or literature studied. This concurs with Ratna (2004: 172) states hypogram is the relations of poetry either words, or sentences that have the same significance or different. Hypogram can also involve historical or cultural conditions at the time the poem was made.

In particular, it can be said that the study of intertextual trying to find certain aspects that already exist in previous works with works that appeared later. Intertextual study itself is to give fuller meaning to literary works. Writing or the emergence of a work is often related to the historical elements thus giving meaning it will be more complete (Teew, 1983: 62). 
In data finding 60, researchers found the use of the same style of Blake's poem, but if viewed as a whole, the poem has a very different meaning. As in the poem 'The Sick Rose' and 'The Garden of Love', which both these poems have the same words, namely 'love' and 'joy'.

In The Sick Rose' poem, the word 'love' represents a relationship. As in the second stanza line 3 "and his dark secret love '. And 'joy' in this poem is joy or pleasure felt by a woman. This is in contrast with the intent to convey Blake in the poem "The Garden of Love". The word 'love' rather to the changes. It is closely related to the second stanza line 3 and 4 "so I turn to the garden of love / that so many flowers bore". And the word 'joy' at the Blake poem means joy or pleasure is restricted.

Blake's poem is born on Romantic era. Where is the hallmark of poetry at this time is more daring, individual, and has captured the imagination of the literary work and life as well.

The idea of creation of Blake's poem influenced and based on the situation before the French revolution. This is what underlies Blake wrote his poems. Because at that time, the French people facing a crisis in many ways. For that Blake wrote the poem "The Sick Rose" and "The Garden of Love".

The next is hypogram contained in the poem "My Pretty Rose Tree" and "The Sick Rose". This poem form of association contained in the word 'rose' and 'night'. The equation of the word 'rose' in this poem is the same as symbolize a woman. If the woman in the poem 'The Sick Rose' is a woman who lost her purity, then the poem 'My Pretty Rose Tree "depicts a woman, or the wife of the speaker's feeling betrayed.

\section{CONCLUSION AND SUGGESTION}

Blake's poem is very interesting to study, especially to analyze symbols by using Riffaterre's theory. Riffaterre's heory has four aspects, there are heuristic and hermenutic reading, matrix, model, variant, and the next is hypogram. 
In the discussion, before describing the heuristic and hermeneutic reading, the researchers are looking for a symbol of poetry first. And the researchers found a symbol in the poem "The Sick Rose", "My Pretty Rose Tree", and "The Garden of Love". They are 'a flower', 'rose', 'thorns', worms, and 'garden of love'.

The conclusion in "The Sick Rose" poem, tells the story of a woman who are sad because of something valuable from her has been lost because of lust and love with a man. She was experiencing pain as a result of her actios. And a man is the cause of all suffering and sorrow in the woman's life. She is only enjoying the night life without thinking aboout the consequences. It is shown in the last line "and his dark secret love does thy life destroy".

In "My Pretty Rose Tree" poem, there is a woman who tried to persuade the speaker's to replace that speaker's wife at home. The beautiful woman said that the man will not feel bored with her, but the man ignores her. A woman (the speaker's wife) who always accompany her husband at home. Her husband always keep her everyday. He is always be honest with her, including when there is another woman who seduce him. She is the special one in her husband's life. But his wife felt jealousy and hatred, because he think her husband has betrayed her.

In "The Garden of Love" poem, depict society that a lot of time. There are so many deviations of religion is considered as a room that can not be touched by the ordinary. The minister made the place a holy place, but in fact, it is just a form of their authority. It is described in the first line of second stanza.

Matrix, models and variants in the third poem studied were as follows; Models in the poem "The Sick Rose" is "and his dark secret love". Then ; (1) The invisible worm, (2) the invisible worm. Then the matrix in the poem 'The Sick Rose', is a person's suffering due to love.

The model contained in the poem "My Pretty Rose Tree 'is" her thorns were my only delight ". The variants were spread throughout the poem, namely; (1) A 
flower was offered to me, (2) but my rose turned away wit Jealousy. The matrix of this poem is the wife of the speaker's jealous and feeling at the betrayers. Models in poem "The Garden of Love" is "that so many sweet flowers bore". The variants that spread to poetry, namely; (1) a chapel was built in the Midst, (2) and the gates of this chapel were shut, (3) and I saw it was filled with graves. And matrix in this poem is the condition of society at that time a lot of changes.

The last step taken is hypogram. Hypogram an intertextual relationship between poetry. Therefore, researchers found hypogram on three poems Blake. The third poem writer Blake studied using the same style, but a different purpose. An example is the 'flower', 'rose', 'joy', and 'night'.

\section{REFERENCES}

Badrun, Ahmad. 1989. Teori Puisi. Jakarta: Depdikbud Direktorat Jenderal Pendidikan Tinggi PPLPTK.

Blake, William. 2016. William Blake Poems. Poemhunter.com-he words poetry archive.

Kaelan. 2009. Filsafat Bahasa : Semiotika dan Hermeneutika, Paradigma: Yogyakarta.

Moody, H.L.B. 1984. Literary Appreciation. United Kingdom: Longman Group Ltd.

Pradopo, Rahmat Djoko. 2010. Pengkajian Puisi: Analisis Strata Norma dan Analisis Struktural dan Semiotik. Yogyakarta: Gadjah Mada University Press.

Ratih, Rina. 2016. Teori dan Aplikasi Semiotika Michael Riffaterre. Yogyakarta: Pustaka Pelajar.

Ratna, Nyoman Kutha. 2004. Stilistika: Kajian Puitika Bahasa, Sastra, dan Budaya. Yogyakarta: Pustaka Pelajar.

Ratna, Nyoman Kutha. 2016. Teori, Metode, dan Teknik Penelitian Sastra. Yogyakarta: Pustaka Pelajar.

Sugiyono. 2013. Memahami Penelitian Kualitatif. Bandung: CV. Alfabeta.

Teew, A. 1983. Membaca dan Menilai Sastra:Kumpulan Karangan. Jakarta: Gramedia.

BRITISH, Jurnal Bahasa dan Sastra Inggris 
